\title{
Acute Myeloid Leukemia with Variant MLL Translocations
}

National Cancer Institute

\section{Source}

National Cancer Institute. Acute Myeloid Leukemia with Variant MLL Translocations. NCI Thesaurus. Code C6924.

A term referring to acute myeloid leukemias with rearrang ement of the MLL gene which results in translocations with various genes other than the MLLT3 (AF9) gene. 